特集 $5^{*}$

食道癌術後栄養管理

経腸栄養と高カロリ一輸液の併用

福自紧立医科大学第 1 外科（主任：本多憲児教授）

坪井正碩森藤 通隆 八子亮

阙野誠川西 政幸 千葉㧝

元木 良一本多 憲児

\title{
POSTOPERATIVE NUTRITIONAL GARE WITH THE ENTERAL AND THE PARENTERAL ROUTE FOR THE ESOPHAGEAL GANGER
}

Masahiro TSUBOI, Michitaka MORITHO, Ryo YAGO, Makoto OKANO, Masayuki KAWANISHI, Atusi CHIBA, Ryoichi MOTOKI, Kengi HONDA

First Depertment of Surgery, Fukushima Medical College

索引用語

\section{I. 緒言}

近年食道癌の手術成績は著しい向上をみたが，手術成 績の向上には手術手技の工夫拉よび術前・術中・術後管 理の進歩が大きく貢献しており,なかでも食道癌手術前 後の栄圼管理は手術成續向上の重要な一因子と考兄られ る.われわれの教室でも手術前後の栄養管理について検 討した成績を発表しているが(2)334)，昭和46年以降食道 癌手術例では経腸栄養法と高カロリ一輸液を併用, 注注 満足出来る成績を得たのでその成績を報告する。

\section{II. 研究対象}

研究の対象とした症例は昭和46年以降昭和51年12月迄 の食道癌切除73例で，これら症例では手術後に経腸栄養 投与に高カロリー輸液の併用を行った。な招昭和 46 年以 前の食道癌切除95例では高カロリ一翰液を併用しないの で,これら症例を対照例とした。これら各症例の癌占居 部位を表 1 亿示す. 対照例では Cが多かったが，昭和46 年以降では Im, Ei が多数を占めた。

\section{III. 栄養投与方法}

経腸栄養投与は手術時にトライッ靬帯より約 $30 \mathrm{~cm}$ の

第 7 回日消外会大会シンポ II

消化器外科々栄盖
装 1 対象症例

\begin{tabular}{c|c|c}
\hline \hline & $\begin{array}{c}\text { 併用群 } \\
\text { S46 S S1.12 }\end{array}$ & $\begin{array}{c}\text { 対 照群 } \\
\text { S 34 } \sim \mathrm{S} 45\end{array}$ \\
\hline $\mathrm{Ce}$ & 5 & 1 \\
\hline $\mathrm{Iu}$ & 1 & 2 \\
\hline $\mathrm{Im}$ & 27 & 19 \\
\hline $\mathrm{Ei}$ & 25 & 20 \\
\hline $\mathrm{Ea}$ & 6 & 6 \\
\hline $\mathrm{C}$ & 9 & 47 \\
\hline & 73 & 95 \\
\hline
\end{tabular}

空腸に造設した空腸栄養瘦より行った。術後晹蠕動, 排 ガスが認められた後に（通常術後 $3 \sim 4$ 日）先ず微温水 より投与を開始し，その翌日より表 2 亿示す教室考案特 別流動食A 上り投与を始めた. その後腹部所見および排 便の状況をみながら特別流動食 B, C と段階的に投与栄 養量を增加した。

高カロリー輸夜は術後 1 〜 2 日は $10 \%$ GL とし, 術後 3 日より尿量，尿糖等を指標に $13 \%$ GL より徐々に糖濃 度を上昇させた。

代表例を図 1 亿示す，症例 No.7071は中部食道癌で 胸骨後食道胃吻合術を行った。術後10\% GL よりの高 
表 2 教室特別流動食

\begin{tabular}{|c|c|c|c|}
\hline & 特別食A & B & $\mathrm{C}$ \\
\hline 卵（個） & 6 & 6 & 6 \\
\hline スキムミルク (gr) & 30 & 30 & 30 \\
\hline リンゴ (g) & 200 & 200 & 200 \\
\hline 食 塩 $(\mathrm{g})$ & 5 & 5 & 5 \\
\hline 蔗 糖 $(\mathrm{g})$ & 100 & 100 & 100 \\
\hline 牛乳 (cc) & 0 & 800 & 800 \\
\hline アミノール（g） & 0 & 40 & 40 \\
\hline 重 湯 (g) & 0 & 600 & 600 \\
\hline バター（g) & 0 & 0 & $20 \mathrm{gr}$ \\
\hline 熱 （cal） & 1100 & 1850 & 2000 \\
\hline 榶（g） & 139 & 230 & 231 \\
\hline 蛋 白（g） & 52 & 86 & 87 \\
\hline 脂 肪 $(\mathrm{g})$ & 37 & 65 & 81 \\
\hline
\end{tabular}

四 1 症例 No. 707161 우

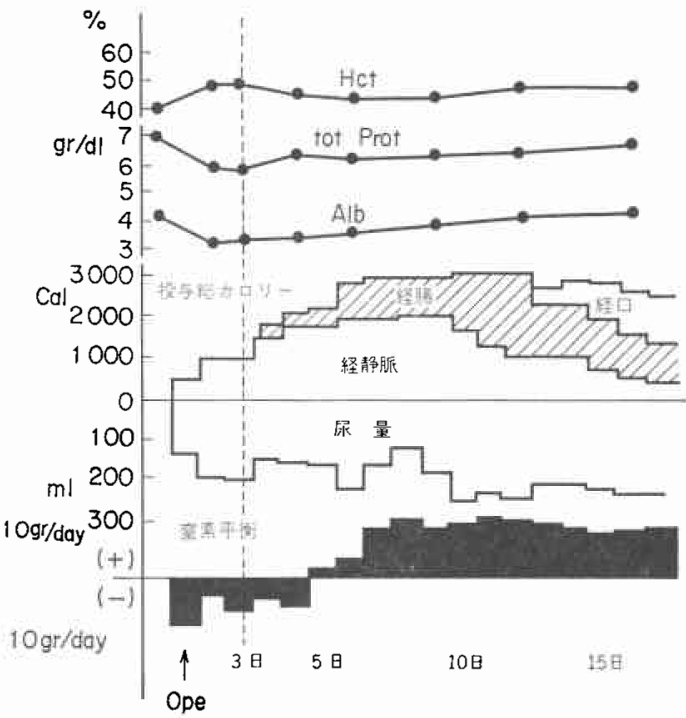

カロリー輸液を施行し,ささらに術後 3 日上り経腸栄養投 与を行った. 術後 6 日には高カロリ一輸液により 1,500 $\mathrm{CaI}$ ，経腸栄養より1,100CaI が投与された。窒素バラン スも術後 5 日には正への移行が認められ, 血清総タンパ ク, アルブミンも術後 5 日より上昇傾向を示し, 術後 14 日には総タンパク $7.2 \mathrm{gr} / \mathrm{dl}, ア ル フ ゙ ミ ン 4.2 \mathrm{gr} / \mathrm{dl}$ と術前値 に回復した，術後12日経口摂取可能となるとともに，高 カロリー輸液を止め, 経晹栄養により $1,800 \mathrm{Cal}$ を投与 し, 経口摂取が充分となるまで経腸栄養投与を行った。
IV. 経腸，高カロリー輸液に併う合併庭，副作用 1）䋊腸栄養に併う副作用（表 3)

高カロり一輸液を併用せずに経腸投与を行った食道癌 切除54例にみられた経腸投与に伴ら副作用は腹部膨満 $38.8 \%$ ，下琍 $29.6 \%$ ，その他が認められたのに対し，高 カロリ一輸液を併用した昭和46年以降症例では, 腹部膨 満,下琍ともに10\%と減少した。

考 3 経腸に併う副作用

\begin{tabular}{|c|c|c|}
\hline & $\begin{array}{l}\text { 経腸群 } \\
\mathrm{S} 40 \sim \mathrm{S} 45\end{array}$ & $\begin{array}{l}\text { I VH併用群 } 73 \text { 例 } \\
\text { S46 S S } 51\end{array}$ \\
\hline 腹部膨满 & $21(38.8)$ & $8(10.9)$ \\
\hline 地 & $16(29.6)$ & $8(10.2)$ \\
\hline 痛 & $4(7.4)$ & $2(2.7)$ \\
\hline 悪 心 & $3(.5 .5)$ & $1(1.3)$ \\
\hline 腸 閉塞 & $1(1.8)$ & $1(1.3)$ \\
\hline 自然抜去 & $1(1.8)$ & $0(0)$ \\
\hline
\end{tabular}

( $) \%$

表 4 高カロリー輸液に併ら合併症

\begin{tabular}{|c|c|c|c|}
\hline $\begin{array}{l}\text { 食道嗝経腸 } \\
\text { 併 }\end{array}$ & 73 例 & その他 & 186 例 \\
\hline \multicolumn{2}{|c|}{ （手技・カテーテルに関するすの） } & & \\
\hline 発 熱 & $17(23)$ & 68 & $(36.5)$ \\
\hline カテーテル感染 & $2(2.7)$ & 22 & (11.8) \\
\hline 菌血症 & 0 & 9 & $(4.8)$ \\
\hline 静脈炎 & $1(1.3)$ & 4 & $(2.1)$ \\
\hline 血栓形成 & $1 *(33)$ & $3 * *$ & $(10.7)$ \\
\hline 血管外注入 & 0 & 2 & $(1.0)$ \\
\hline 気 胸 & 0 & $1 * * *$ & $(1.9)$ \\
\hline 動脈穿剌 & 0 & $1 * * *$ & $(1.9)$ \\
\hline \multicolumn{2}{|c|}{ （代謝に関する合併症） } & & \\
\hline 高血楉 & $2(2.7)$ & 6 & ( 3.2$)$ \\
\hline 浸透圧利尿 & $2(2.7)$ & 5 & (2.6) \\
\hline 肝障害 & 1. (1.3) & 2 & $(1.0)$ \\
\hline 低血糖 & 0 & 1 & $(0.5)$ \\
\hline 脂肪肝 & $0^{*}$ & $10^{* *}$ & ( 5.3$)$ \\
\hline
\end{tabular}

剖検: *3 例, $* * 28$ 例

銷骨下穿刺: ****51例

() $\%$

2）高カロリー輸液に伴う合併症（表 4)

食道癌経腸併用群73例と, その他消化器疾患で経腸投 与を併用せず高カロリー輸液を行った186例について， 高カロリー輸液に伴う合併症について比較した，食道癌 経腸併用群では, 発熱, カテーテル感染，菌血症などの 手技・カテーテルに関する合併症の発生は少数であり， また代謝に関する合併症す少数例にみられたのみであっ た. 


\section{V. 検查成續}

血清総タンパク，血清フルブミン，窒素平衡，血清ア ミノ酸について手術前後に測定した成績についてのべ る.

1）血清総タンパク，血清アルブミン值

血清総タンパク,フルブミンの変動を図 2 に示す. 血 清総タンパクは術後早期に低下をみるが，対照群症例で はその上昇傾向は 7 日以降と抙く, 術後 14 日もな和低值 であった，しかし，併用群では術後 5 日には軽度の上昇 傾向を示し，術後14日には6.6gr/dl (対照群 $6.2 \mathrm{gr} / \mathrm{dI}$ ) と 上昇をみた。

図 2 血清タンパタフルブミンの変眮

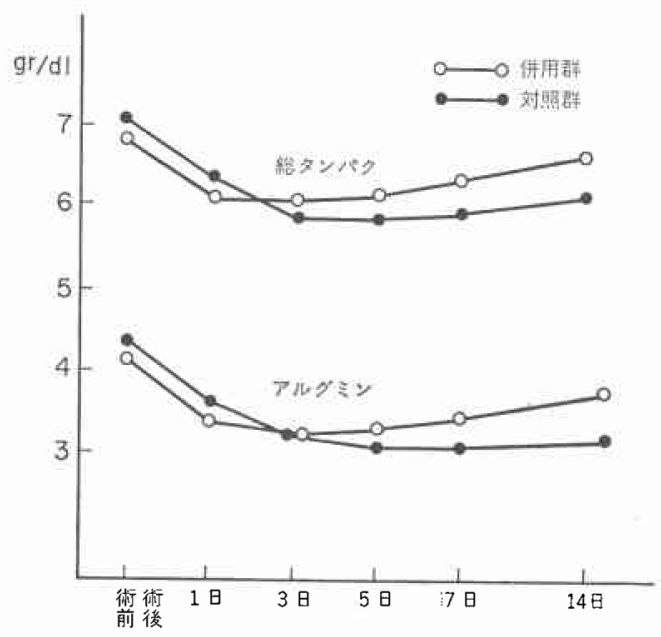

血清アルブミンの変動も総タンパク同様の傾向を示し た.すなわら対照群では術植後低下し，術後14日にもな お低值のままであったが，併用群では術後 7 日に上昇傾 向を示し, 術後14日には3.7gr/dl（対照群3.3gr/dl）まで 回復を示した。

2) 窒素平衝 (図 3)

投与総空素量と尿中窒素排泄量より術後の窒素平衝を みると，対照群において術後 7 日でもー3gr/day の負の 平衡を示したが, 併用群では術後 7 日には+2gr/dI と負 より正への移行が早期に認められた。

3）血清遊離アミノ酸

血清遊離アミノ酸の術後の变動をみると, 総アミノ酸 は術後低下し, 術後 3 日最低值を示し, 術後 $5 \sim 7$ 日上 り上昇し，術前値に回復する傾向を示した．しかし，対 照群では回復が遅延し14術後日でも術前の80\%であった のに反し, 併用群では術後 5 日以降の回復が早く, 術後
図 3 血清遊離アミノ酸の変動
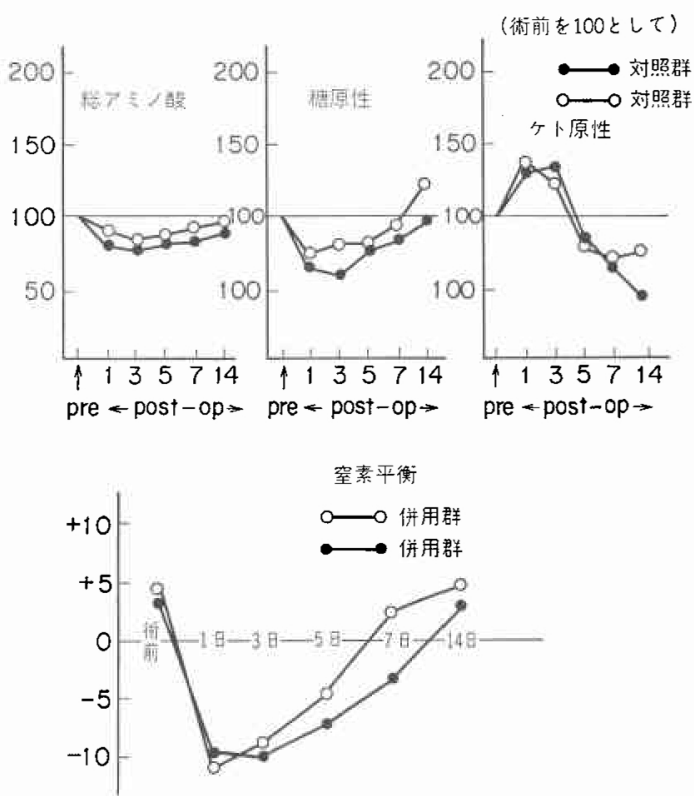

14日には術前値比97\%まで回復した。

血清遊離アミノ酸を糖原性, ケト原性アミノ酸につい ても，打の和のともに，対照群の回復遅延が認められ， 併用群での回復が良好であった。

\section{VI. 手術成績 (表 5 )}

手術成績を直接死亡, 縫合不全についてみると, 対照 群では直死率23\%であったが，併用群では 6 例，8\%と 著しい減少を認めた．また縫合不全発生例についてみる と対照群では瘦孔の治癒をみた症例はわずか16例中の 2 例であったのに反し, 併用群11例では 8 例に瘦孔の治癒 をみた。

表 5 手術成績

\begin{tabular}{|c|c|c|c|c|c|c|}
\hline & \multicolumn{3}{|c|}{ 併 用 群 } & \multicolumn{3}{|c|}{ 対照 群 } \\
\hline & 切除数 & $\begin{array}{l}\text { 释 合 } \\
\text { 全 }\end{array}$ & 直 死 & 切除数 & 䋖 合 & 直 死 \\
\hline 頝胸部 & 58 & 9 & 5 & 42 & 12 & 15 \\
\hline \multirow[t]{2}{*}{ 腹 部 } & 15 & 2 & 1 & 53 & 4 & 7 \\
\hline & 73 & 11 & $6(8)$ & 95 & 16 & $22(23)$ \\
\hline
\end{tabular}

\begin{tabular}{|c|c|c|c|}
\hline & & \multicolumn{2}{|c|}{ 组合不全 } \\
\hline & & 非沇被 & 治 楼 \\
\hline 対間群， & 95 & 14 & 2 \\
\hline 併用群 ? & 73 & 3 & 8 \\
\hline
\end{tabular}


VII. 合併㱏発現時の栄意管理

食道癌術後には各種術後合併症の発現をみ, 必ずしも 経腸，高カロリー輸液が充分に行うことが不可能となる 場合がある.しかし併用療法を行うことにより投与 Cal を低下させずに管理を行らことができる．次に代表的合 併症である縫合不全, 肺合併症発生例を示す。

症例 No. 7498 (図 4) は Ea で右胸腔内食道胃吻合 術を行つた．術後高カロリ一輸液を行らとともに術後 4 日より経腸栄養を開始した，経腸栄養を開始すると経鼻 胃管よりの吸引量が $400,600 \mathrm{ml}$ と增加する傾向を示し た. 術後 5 日吻合部の縫合不全が確認されたためにドレ ナージを行うとともに縫合不全部の拡大を恐れ経腸投与

图 4 症例 No. $7498 \quad 49 \hat{\partial}$

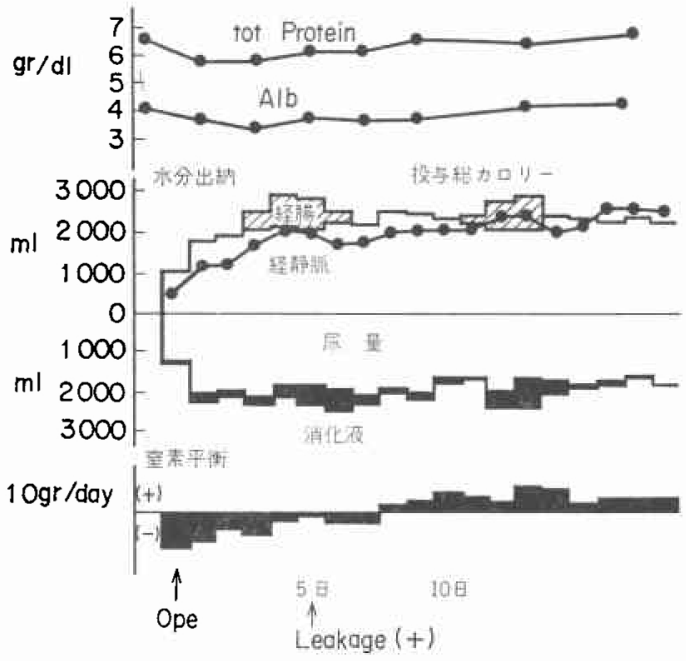

を中止し，高カロリ一輸液により以後管理を行った。

一方症例 No. 7353 (図5) は Im により胸骨後食道 胃吻合術を行ったが, 術後 2 日より胸部にラ音が聴取さ れ術後 2 日 $2,800 ， 3$ 日 $2,600 \mathrm{ml}$ の輸液を行うに術後 4 日泡沫状喀痰が出現した，その時には肺動脈圧の著しい 上昇が認められ，補液制限，利尿剂投与を行わざるを得 なく，術後 4 日には補液を1,400 $\mathrm{ml}$ と減少させたため， 高カロリー輸液では充分な Cal 量を投与できなくなっ たが，その後は経腸栄養を中心に行らことにより投与 Cal を減少させずに, 肺所見の改善もみた（図6).

\section{考案}

食道癌患者においては術前経口摂取不能の症例が多 く, 手術侵襲も過大で異化期が遅延し易く，また術後長 期に亘り経口桙取不能状態が続く．したがって食道癌患
125 症例 No. $735360 \hat{0}$

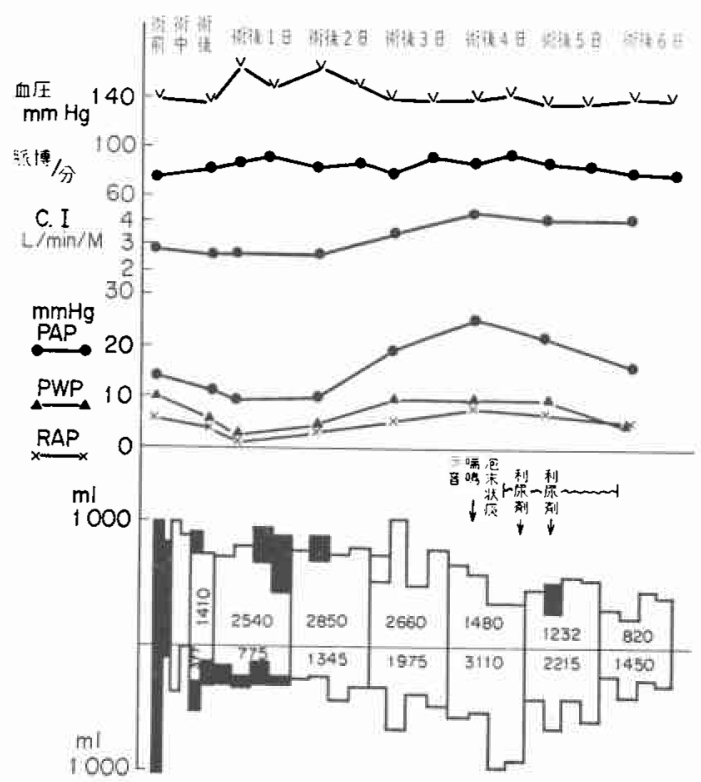

图 6 症例 No. 7353

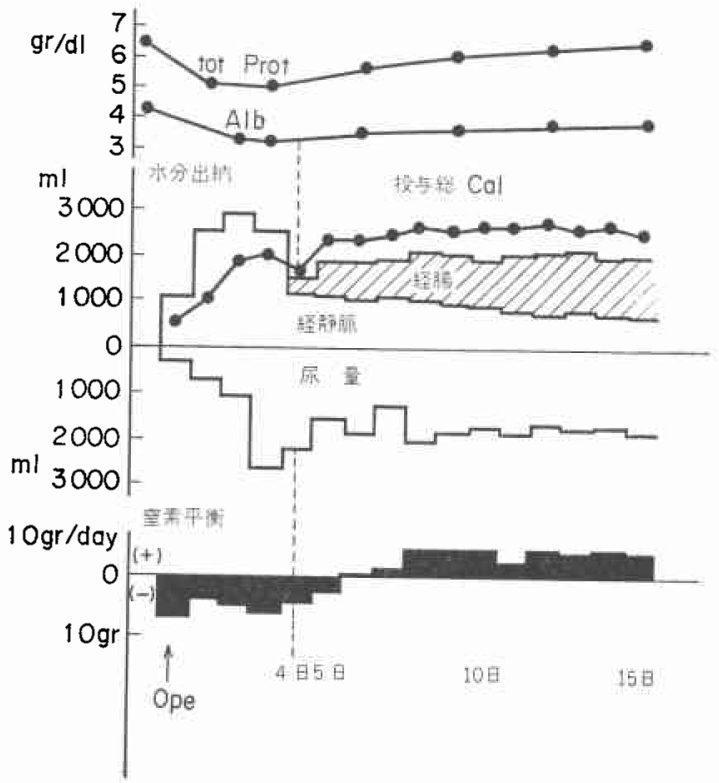

者では低栄養状態に伴う合併症を起し易く，手術成績向 上のためには栄養管理は極めて重大な問題である.

経口掑取不能症例に対する経腸栄養投与は古くから行 われており (5)，われわれの教室においてあ本多ら"，小 関 ${ }^{2}$ ，渡辺 ${ }^{3)}$ らがその成績を発表して来た。経腸栄養は 
諸家の指摘する如く栄養改善の効果は大きいが, 問題点 の1つとして術直後から経腸栄養投与を開始することが 出来ず, 腸蠕動, 排ガスの認められる術後 3 日以降から 本格的投与が可能となり，術直後より充分量を投与する ことは極めて困難である。また経腸栄養投与に伴う腹部 膨満, 下莉, 腹痛などの副作用も問題の 1 つである.お れわれの症例に叔いて束腹部膨満，下痢ともに30〜 40\% 認められ，諸家報告の20～50\% 7) 879) とほぼ同様の成績 で，投与を中止または減量を余儀なくされた症例が多数 認められた。

一方, 最近 Dudrick ${ }^{10)}$ らにより普及された高カロリ一 輸液が食道癌手術前後に利用される様になり, その効果 は諸家 ${ }^{112)}$ の認めるところである. しかし小野寺 ${ }^{13)}$, 岡 田ら ${ }^{14)}$ が指摘する如く高カロリー輸液にも種々の問題点 が残されている、すなわらわれわれの症例にみる如く， 発熱, 菌血症等手技・カテーテルに関する合併症, さら に高血糖，漫透圧利尿，脂肪肝などの代謝に関する合併 症が指摘されており，これら合併症のために高カロリー 輸液を中止せざるを得ない場合もしばしば認められる。

そこでわれわれは経腸栄養, 高カロリ一輸液のそれぞ れの欠点を補い合い, 充分な栄養を投与出来るよらに食 道癌術後症例に，両者の併用を利用して来た。経腸栄 養, 高カロリー輸液を併用することにより, 経腸より無 理に投与量を増加する必要がなく，また，高力口リ一輸 液による補液量を增加させず, 無理に高濃度にせずに高 カロリーが投与出来た。この併用療法を行らことにより 従来30 40\%認められた経腸投与に伴ら腹部膨満, 下浰 の副作用は10\%に減少させることが出来, さらに高力口 リ一輸液を伴う発熱等の合併症む併用群では少数例にみ られるのみであった。

さらにわれわれの検查成績からも併用療法の有用性が 認められた。すなわち血清タンパク，アルブミン量の変 化からみて, 併用群ではその回復が対照群より早期に認 められた．術後早期に侀用群で回復傾向が認められたの は Gamble ${ }^{15)}$ の言う如く, 術直後より高 Cal 投与によ り術後の蛋白崩壊が抑制されたものと思われる。

術後の窒素平衡よりみれば負より正への移行がわれわ れの対照例では 7 日以降, 赤倉 ${ }^{15)}$, 福田 ${ }^{17)}$, 佉野ら ${ }^{18)}$ の 症例でも同様であったが, われわれの併用群では術後 7 日には正への移行が認められ巽化期の短縮を示唆してい るものと思われる。

血清アミノ酸の面よりみても総アミノ酸, 生体のエネ ルギー源となる糖新生に利用されると言われる ${ }^{199}$ 糖原性
アミノ酸は術後減少傾向をみるが，その減少は併用群で 軽微であり，さらにその回復が良好であったことは併用 群において適切な熱源が投与されたためと考觉られた。

食道癌術後合併症発現時の栄養管理はさらに重要な問 題である．著者は最るしばしば遭遇する合併症である縫 合不全, 肺合併症の 2 例を示した。縫合不全発生時には われわれの症例の如く, 症例によっては経腸栄着投与に より消化液の分泌増加を来たし縫合不全部桩大の恐れが あり，経腸栄羵投与が不適当な場合がある。一方肺合併 症発現時にはわれわれの成績では肺動脈圧上昇を示す症 例が多く ${ }^{2021)}$ ，水分投与を制限せざるを得ない場合が多 く補液のみにより高 $\mathrm{Cal}$ を投与することが不可能であ る。このような合併症発現時にも併用療法を行へば不利 な一方をひかえ目にして，栄責投与を中断することがな く, 高力口リ一投与継続可能であり, 併用療法が有利で ある。

以上のことからみて食道癌術後には経腸・高カロリー 輸液の併用は術後栄養管理上極めて有用な手段であると 考点られた．本法施行前と施行後のわれわれの手術成績 向上の差は単に栄養管理上の差のみとは言えず，手術手 技，その他術前・術中・術後管理の向上と相まって， 栄養管理向上が重要な一因となっているものと考えられ た。

\section{結 語}

食道癌術後の栄養投与法としてわれわれが行っている 経腸栄養投与と高力ロリ一輸液の併用について述べた。 本法は経腸, 高カロリー輸液のおのおの欠点を補い合 い, 充分な栄養投与が可能であり, 血清総タンパク，ア ルブミン, 窒素平衡, 跙清アミノ酸等の面よりみても術 後管理上有利であった。

\section{文献}

1) 林多憲昆他：老人外科飞未小る死亡例の検討. 外科, $28: 1284 \sim 1292,1966$.

2) 小関雅之: Poor risk 及び高命者手術に対する 術後空踢栄粮補給例の臨休的観察。日外会誌, $68: 1000 \sim 1024,1967$.

3）渡辺徳夫：高令者外科の研究. 第 5 報, 日外会 誌, $69:$ 1580 1601, 1968.

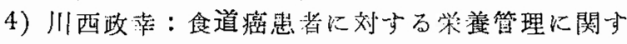
る研究。福島医誌, 投稿中, 1977 .

5) 小山恒明他：食道癌根治手術に扮ける栄美学的 籍問題. 外科, 24 ： 343 347, 1962.

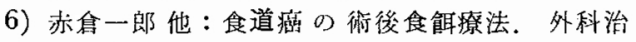
撩, $6: 208 \sim 218,1961$.

7）浜口栄鿆他：経腸栄養时の下瘌とその対策。治 
療, $41: 43 \sim 46,1963$.

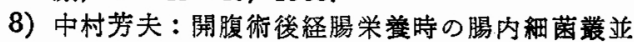
びに下㜀に関する研究. 日外会誌, 64：240 $274,1963$.

9）加固叔夫他：食道癌および噴門癌に対する術前 高カロリ一輸液. 日消外会誌, 9 ： 355 362, 1976.

10) Dudrick, S.T. et al.: Long-term parenteral nutrition with growth development and positive nitrogen balance.: Surg., 64: 134 142, 1968.

11）葛西森夫他: 最近の完全静脈栄養法. 手術, 27: 9, 922 929, 1973.

12）加固䄫夫他：高令者術後管理における経中心静 脈栄養法の検討. 術後代謝, 8: 131 136,1974.

13）小野寺時夫：現代外科学大系, 75: B , 1975 .

14) 岡田正他: 高カロリー輸液の実際. 外科治
療, 29 ： 340 346, 1973.

15) Gamble, J.L.: Chemical anatomy, physiology of extracellular fluid, 1949. Harvard Univ Press., Cambridge.

16）赤倉一郎他：食道螘手術の困難性火ついて，日 胸外会誌, 8：602〜610, 1955 .

17) 福田 保他: 術前後の栄羞管理. 臨床栄善, 25: $12 \sim 16,1969$.

18）佐野 㠱他：食道癌術後管理における経中心静 脈栄蓄法. 術後代謝, 6：149～153，1972.

19）市原四郎：アミノ酸と糖代謝. 代謝, $7: 317 \sim$ $321,1970$.

20）元木良一他：食道癌手術後の血行動態よりみた 術後管理について. 日外会誌, $77: 384 \sim 385$, 1976.

21）坪并正碩：食道癌術後脯合併症に関士る研究. 日外会誌, $78: 223 \sim 231,1977$. 